Wawrzyniec WAWRZYNIAK

Embryology

\title{
AN ATTEMPT ON THE ARTIFICIAL SPAWNING AND EGGS INCUBATION OF HERRING (CLUPEA HARENGUS L.) OF PUCK BAY ORIGIN
}

\author{
PRO̊BA SZTUCZNEGO TARÆA IINKUBACJI IKRY ŚLEDZIA \\ (CLUPEA HARENGUS L.) ZZZATOKI PUCKIEJ
}

\section{UNIVERSITY OF STETTIN}

\begin{abstract}
Spawning and eggs incubation of herring (Clupea harengus L.) of the Pucka Bay origin were carried out. During incubation period measures of the water oxygen content $\left(\mathrm{mg} / \mathrm{dm}^{3}\right)$ and water temperature $\left({ }^{\circ} \mathrm{C}\right)$ had been taken. The particular eggs developing stages were determined in degreedays $(D)$. Efforts, as to find out wheather, rinsed with marine water mixed with milk, eggs are loosing their sticking properties were undertaken. After being sticked to the net, eggs were incubated directly in the Bay water and controlled while incubating.
\end{abstract}

\section{INTRODUCTION}

An interest in herring as the fish species has been lasting for years, mainly because of its great economic importance. Up the date survays, carried out in Poland, havent been directed, basically, on the herring artificial spawning and eggs incubation. The first work on the subject (Brock, 1885) deals with this phenomenon after the fish death including eggs incubation of the Scottish herring. There are also works on the effect of salinity and temperature on developing eggs of herring from the North Sea, Baltic Sea, Atlantic Ocean and Pacific Ocean (Krzyżanowskij, 1956 ; Gałkina, 1956; Blaxter, 1960; Holliday, 
Blaxter, 1960).. However, individual embriogenesis stages, in degree-days have not been determined.

So, the decission was to carry out an artificial spawning, to fertilize eggs and do some observations on their development. Besides, it was to find out, wheather milk addition to marine water results in the eggs' sticking properties loss and for how long, after the fish death, the gametes keep their fertilizing properties. Yet an effort as to determine the degree-days amount for each development stage, was undertaken.

Furthermore, a possibillity for artificially fertilized eggs to develope under the natural conditions, at so called artificial spawning grounds, was tested.

\section{MATERIAL AND METHODS}

Surveys were conducted on the spring herring being caught within the Puck Bay in May and June. First spawning was carried out two hours after the fish death. Gametes were being kept within the daed fish gonads up to 4.5 hours at the temperature $5^{\circ} \mathrm{C}$ to $10^{\circ} \mathrm{C}$ with spawning carried out every half an hour. Fertilization took place in water of $4.33 \%$ salinity and the temperature $5^{\circ} \mathrm{C}$, resembling the spawning ground conditions. Eggs were incubated under the same water conditions at $9^{\circ} \mathrm{C}$ to $14^{\circ} \mathrm{C}$ in the Petri dishes; with water being exchanged every 24 hours and oxygen content in water being $9 \mathrm{mg} / \mathrm{dm}^{3}$.

A fertilization was carried out as follows: fish eggs after being spawned at Petri dish were covered with milt and suspended thoroughly in water. Then, after 10 minutes eggs were washed with natural water from the Puck Bay and resuspended in it, in two variants. With small eggs inoculum of 1 to $13 \mathrm{eggs} / \mathrm{cm}^{2}$ and high inoculum, i.e. 30 to 50 individuals $/ \mathrm{cm}^{2}$.

As to cause the eggs to loose their sticking properties washing in marine water and milk mix ture $1: 1$ was applied.

Fish were spawned directly onto net, with a mesh size $10 \mathrm{~mm}$, within the bowl, thanks to a stiking proporties of the eggs. After being sprinkled with milt eggs were covered with water from the Bay and evenly distributed onto a net. When rewashed after 10 minutes net without the bowl was being drawned in the Bays' waters close to the coast line, attached to two pales anchored to the bottom.

Fertilization was read after a blastospore closure. Observations were carried out daily under a binocular.

\section{RESULTS}

From a biological point of view the surveys proved there to be a possibillity for artificial spawning, fertilization and incubation of eggs of the spring herring. According to the data in Table 1, fertilization following an artificial spawning takes place in over $90 \%$ of eggs under fertilization, with gamets being kept within the dead fish gonads for 4 hours. 
Effect of the storage time in gonads of dead herring from

Puck Bay on the eggs fertilization percentage

\begin{tabular}{|c|c|c|c|}
\hline \multicolumn{2}{|c|}{ Storage time - in gonads } & Fertilization & \multirow{2}{*}{ Notices } \\
\hline hours & $\min$. & & \\
\hline $\begin{array}{l}2.5 \\
3.0 \\
3.5 \\
4.0 \\
4.5\end{array}$ & $\begin{array}{l}150 \\
180 \\
210 \\
240 \\
270\end{array}$ & $\begin{array}{l}98.51 \\
98.20 \\
95.15 \\
92.31 \\
61.10\end{array}$ & large eggs concentrations \\
\hline $\begin{array}{l}2.0 \\
2.5 \\
3.0\end{array}$ & $\begin{array}{l}120 \\
150 \\
180\end{array}$ & $\begin{array}{l}75.10 \\
25.10 \\
20.20\end{array}$ & $\begin{array}{l}\text { eggs undergoing fertilization } \\
\text { in water-milk micture - large } \\
\text { concentrations }\end{array}$ \\
\hline 3.0 & 180 & 89.10 & $\begin{array}{l}\text { eggs undergoing fertilization in water-milk } \\
\text { mix ture - small concentrations }\end{array}$ \\
\hline
\end{tabular}

Percent of fertilization for the eggs exposed to fertilization in marine water mixed with milk was lower and depended on the eggs' storage time in gonads. For small eggs inoculum, a fertilization, after 3 hours storage in gonads was equal to $89.1 \%$. With high eggs' inocula a fertilization was already lower after 2 hours' storage within the dead fish gonads, yet dropping to $20.2 \%$ after 3 hours' storage (Tab. 1). When washed with water milk mixture eggs did not loose their sticking properties, however washing affected essentially fertilization abbility.

During fertilization, 5 to 10 minutes after being poured with water eggs show strong sticking effect attaching easily to bottom of Petri dish or to net. Nonfertilized eggs do not give such a strong sticking effect.

During first development stage, i.e. from the moment of fertilization to a blastospor closure eggs develope rather evenly. Differences in development rate become clear during organogenesis reaching up to $32^{\circ} \mathrm{D}$ at the moment of hatch (Tab. 2).

Observations indicated the percentage of fertilization to be lower for the eggs in higher concentrations. Besides their development was described as slower and uneven. Eggs inside the clusters become, often, whiter right before the hatch, with a hatch moment being much longer when compared with the one for the eggs from an outer part of the cluster. For embryos in large concentrations an unproper development is to be observed. Larvas hatched from such clusters give evidence to that. They show numerous teratological changes, such as spine contortion (by a caudal fin), spiral and oval contortions of the whole spine. According to eggs concentration, up to $60 \%$ of hatched larvas can show teratological changes.

Each development stage was described in degree-days (Tab. 2). Surveys were carried out in Petri dishes, which made the observation easier. According to observations, 
Incubation time of the spring herring development stages expressed in degree-days $\left({ }^{\circ} \mathrm{D}\right)$

\begin{tabular}{|c|c|c|c|c|c|c|}
\hline \multirow[b]{2}{*}{ Stage of development } & \multirow{2}{*}{$\begin{array}{l}\text { water } \\
\text { temp. } \\
\left({ }^{\circ} \mathrm{C}\right)\end{array}$} & \multicolumn{5}{|c|}{ Incubation length } \\
\hline & & $\begin{array}{l}\text { date } \\
\text { of } \\
\text { sur }\end{array}$ & $\begin{array}{l}\text { hour } \\
\text { of } \\
\text { ys }\end{array}$ & $\begin{array}{l}\text { in } \\
\text { days }\end{array}$ & & $\begin{array}{l}\text { er of } \\
{ }^{\circ} \mathrm{D}\end{array}$ \\
\hline $\begin{array}{l}\text { fertilization } \\
\text { straition }\end{array}$ & $\begin{array}{r}5.0 \\
11.0\end{array}$ & 12.05 & $\begin{array}{l}12^{00} \\
19^{00}\end{array}$ & $\begin{array}{l}0.00 \\
0.29\end{array}$ & $\begin{array}{l}0 \\
7\end{array}$ & $\begin{array}{l}0.00 \\
2.32\end{array}$ \\
\hline $\begin{array}{l}\text { end of striation } \\
\text { egg yolk's coverage in } 1 / 3\end{array}$ & $\begin{array}{r}9.0 \\
11.0\end{array}$ & 13.05 & $\begin{array}{r}7^{00} \\
19^{00}\end{array}$ & $\begin{array}{l}0.79 \\
1.29\end{array}$ & $\begin{array}{l}19 \\
31\end{array}$ & $\begin{array}{r}6.58 \\
11.61\end{array}$ \\
\hline $\begin{array}{l}\text { egg yolk's coverage in } 2 / 3 \\
\text { blastospore closure }\end{array}$ & $\begin{array}{l}11.0 \\
10.6\end{array}$ & 14.05 & $\begin{array}{l}11^{00} \\
19^{00}\end{array}$ & $\begin{array}{l}1.96 \\
2.29\end{array}$ & $\begin{array}{l}47 \\
55\end{array}$ & $\begin{array}{l}18.42 \\
21.98\end{array}$ \\
\hline $\begin{array}{l}\text { visible embryo } \\
\text { embryo with visible eyes } \\
\text { embryo tail separates from } \\
\text { egg yolk, visible miomers }\end{array}$ & $\begin{array}{l}10.0 \\
11.0 \\
11.0\end{array}$ & 15.05 & $\begin{array}{r}7^{00} \\
17^{00} \\
24^{00}\end{array}$ & $\begin{array}{l}2.79 \\
3.20 \\
3.50\end{array}$ & $\begin{array}{l}67 \\
77 \\
84\end{array}$ & $\begin{array}{l}26.95 \\
31.42 \\
34.83\end{array}$ \\
\hline $\begin{array}{l}\text { heart actions begining } \\
\text { normal heart action, embryo } \\
\text { begins to move } \\
\text { head separates from egg yolk, } \\
\text { beginning of tail separation } \\
\text { in large concentrations }\end{array}$ & $\begin{array}{l}11.1 \\
12.0 \\
11.2\end{array}$ & 16.05 & $\begin{array}{r}7^{00} \\
16^{00} \\
24^{00}\end{array}$ & $\begin{array}{l}3.79 \\
4.17 \\
4.50\end{array}$ & $\begin{array}{r}91 \\
100 \\
108\end{array}$ & $\begin{array}{l}38.17 \\
42.10 \\
46.44\end{array}$ \\
\hline $\begin{array}{l}\text { strong embryo movements, } \\
\text { primary eyes pigmentation }\end{array}$ & $\begin{array}{l}11.8 \\
13.6\end{array}$ & 17.05 & $\begin{array}{r}7^{00} \\
20^{00}\end{array}$ & $\begin{array}{l}4.79 \\
5.29\end{array}$ & $\begin{array}{l}115 \\
127\end{array}$ & $\begin{array}{l}49.96 \\
56.39\end{array}$ \\
\hline $\begin{array}{l}\text { eyes pigmentation, } \\
\text { beginning of body pigmentation }\end{array}$ & $\begin{array}{l}12.8 \\
14.5\end{array}$ & 18.05 & $\begin{array}{r}7^{00} \\
20^{00}\end{array}$ & $\begin{array}{l}5.75 \\
6.29\end{array}$ & $\begin{array}{l}138 \\
151\end{array}$ & $\begin{array}{l}62.16 \\
69.44\end{array}$ \\
\hline $\begin{array}{l}\text { different stages of eyes } \\
\text { and body pigmentation }\end{array}$ & 13.0 & 19.05 & $12^{00}$ & 7.00 & 168 & 77.98 \\
\hline $\begin{array}{l}\text { differences in development } \\
\text { from eyes pigmentation to full } \\
\text { body pigmentation } \\
\text { beginning of hatch }\end{array}$ & $\begin{array}{l}13.00 \\
12.00\end{array}$ & 20.05 & $\begin{array}{l}18^{00} \\
23^{00}\end{array}$ & $\begin{array}{l}8.25 \\
8.46\end{array}$ & $\begin{array}{l}198 \\
203\end{array}$ & $\begin{array}{l}92.81 \\
95.51\end{array}$ \\
\hline mass hatch & 13.1 & 21.05 & $12^{00}$ & 9.00 & 216 & 102.42 \\
\hline mass hatch & 13.6 & 22.05 & $12^{00}$ & 10.00 & 240 & 114.90 \\
\hline end of hatch & 14.0 & 23.05 & $12^{00}$ & 11.00 & 264 & 127.60 \\
\hline
\end{tabular}


herring's growth from fertilization moment up to hatch, lasted, at the water temperature from $9^{\circ} \mathrm{C}$ to $14^{\circ} \mathrm{C}, 95.5^{\circ} \mathrm{D}$ to $127.6^{\circ} \mathrm{D}$. An oxygen content of the water was equal to $9 \mathrm{ml} / \mathrm{dm}^{3}$. Under these conditions a mass hatch was noted between $102^{\circ} \mathrm{D}$ and $115^{\circ} \mathrm{D}$, with difference between a begining and end of hatch equal to $32^{\circ} \mathrm{D}$. Evolution of individual development stages in relation to degree-days $\left({ }^{\circ} \mathrm{D}\right)$ are presented in Table 2.

Due to a sticking properties of the herring's eggs, it was possible to spread them evenly onto net during fertilization process. Fertilized eggs sticked to the net after few minutes. The net was then drawned close to the shore and attached to two.pales anchored at the bottom in the way enabling an oxygen to reach the eggs freely. That way the eggs were incubated until the hatch.

Development of eggs, both onto net and within Petri dishes was observed at the same time. The growth rate, presented in Table 2, as well as processes described above proceeded similarly.

\section{DISCUSSION}

Surveys on artificial spawning, fertilization and incubation of the herring's eggs proved such activity to be succẹsfull with the herring. For eggs being kept for 4 hours, within the dead fish gonads, a $90 \%$ fertilization was noted (Tab. 1). According to the Brook's surveys (1885) fertilization was still possible after 40 hours storage of eggs within the dead fish gonads. However milt could have kept that property up to 3 hours only.

During fertilization process, eggs were washed with the Bay's water of $4.3 \%$ salinity (a salinity of the spawning ground area), which resulted in $90 \%$ eggs being fertilized. A fertilization effect for eggs washed with 1:1 water-milk mix ture was lower. Results obtained are presented in Table 1. An explanation to that may be to low water salinity (consed by milk addition), for carrying fertilization process properly.

Development of herring (Clupea harengus L.) of the Northern Atlantic, North Sea anc the Baltic Sea origin takes place in waters with $5 \%$, salinity, with the hatch being observed at $4.8 \%$ (Holliday, Blaxter, 1960). McMynn and Hoar (1953) had noticed a high tolerance of pacific herring (Clupea harengus pallasii Val.) towards water salinity; not lower, however, during development than $6 \%$. According to Gałkina (1957) the fertilization effect for the Ochocki herring was highest when water salinity ranged from $5 \%$ to $33 \%$, with development course and hatch proceeding correctly in waters of $4 \%$ salinity.

A water salinity from the Bay, used for washing purposes in this experiment, was equal to $4.33 \%$. Therefore, that salinity can be assumed as optimal for herring's spawning within the Puck Bay. An addition of milk, by lowering the water salinity. lessened the fertilization effect. According to both; the cited literature and observations, a fertilization process itself requires higher water salinity than does the development of the fertilized eggs. The subject requires, however, further studies. A goal, as to unstick the eggs with milk, has not been reached. 
Incubation of the herring's eggs, at $9^{\circ} \mathrm{C}$ to $14^{\circ} \mathrm{C}$, lasted from 9 to 11 days, that is ranged from $95.5^{\circ} \mathrm{D}$ to $127.6^{\circ} \mathrm{D}$ (Tab. 2). Results of Krzyżanowski's (1956) work confirm these observations. Although carried out under somewhat different conditions (25 $\% 0$ water salinity and $18^{\circ} \mathrm{C}$ of the water) surveys indicated the incubation process itself, time it lasted (Tab. 2) and teratological changes in larvas to be similar. Water temperature within the Petri dishes, where the incubation took place, was by $2^{\circ} \mathrm{C}$ to $3^{\circ} \mathrm{C}$ higher than the one at the fishing ground in the Bay, where experimental nets were incubated. Therefore we can assume the water temperature to resemble the one under natural conditions. Also Hessle (1925) and Demel (1928) indicated $6{ }^{\circ} \mathrm{C}$ to $10{ }^{\circ} \mathrm{C}$ water temperature to be suitable for spawning of the spring herring in the Baltic Sea. According to Nikolski (1970) an incubation time for the eggs of all the Clupea harengus L. forms differs due to the water temperature and may last from 7 to 50 days, with water temperature ranging from $0^{\circ} \mathrm{C}$ to $15^{\circ} \mathrm{C}$.

With proper parameters of the water during incubation process; that is proper oxygen content, water temperature and salinity, there are differences in the development course between small and large eggs concentrations (Tab. 2). Differences in development process between the eggs, particularly clear in big clusters, are caused probably by uneven access of an oxygen to the eggs. Too low oxygen content in water compared to a need for it by a developing egg, may result in different developing rate, teratological changes of embryos and larvas and death. In big clusters eggs from its outer part absorb oxygen unabling its further penetration inside the cluster. Fridland's (1951) observations on spawning and eggs development of Schaliński herring proved this.

Spawning of herring takes place either on a gravel, stony ground or a ground cowered with water plants. In both cases eggs, while falling down during spawning process, remain at various levels, forming layers permitting free oxygen access to the eggs. Direct observations of herring's spawning grounds, carried out by Lubieniecki, Zawadzki (1980) confirmed that. Oxygen content in water is additionally affected by the assimilation process of algas and other water plants herring's eggs are being attached to. While sticked to nets, herring's eggs were incubated directly in the Bay waters until the hatch. In small eggs clusters hatch was noted in all eggs within the cluster, while in large ones upt to 50\% of white grains was noted. It was often observed, when catching the spawning herring, the nets to be sticked up with eggs. There is where the idea for using the nets came from. Conditions, for the eggs sticked up to nets, resemble natural ones. A direct control of development process is possible and this method can be applied as an artificial hatchery an artificial spawning ground.

Surveys done proved there to be a possibility for artificial spawning of herring and direct observations conducted on the eggs development.

\section{CONCLUSSIONS}

1. There is a possibility for artificial spawning, fertilization and incubation of the spring herring. 
2. Incubation time of the spring herring lasts from $95.5^{\circ} \mathrm{D}$ to $127.6^{\circ} \mathrm{D}$, that is 9 to 12 days at $9^{\circ} \mathrm{C}$ to $14^{\circ} \mathrm{C}$ and water salinity of $4.3^{\circ} \% 0$.

3. When in large concentrations, herring's eggs develop slower and get white often before the hatch is over. Besides teratological changes in larvas happen quite often.

4. Eggs, up to a blastospore closure moment, develop evenly. Since the emryo formation, differences in development rate become more and more visible, reaching $32^{\circ} \mathrm{D}$ before the hatch.

5. There is a possibility to use nets as an artificial spawning ground, taking adventage of the eggs' sticking properties.

\section{REFERENCES}

Blaxter J.H.S., 1960: The effect of extremes of temperature on herring larvae. - J. mar. biol. Ass. U. $K_{.}, 39:$ 605-608.

Brook G., 1885: On the developmend the herring. - Rap. of the Fishery Board of Scotland. Edinburg.

Demel K., 1928: Wyróżnienie ras śledzi poławianych u naszych wybrzeży. [Distinguishing between herring races caught along the Baltic coast of Poland]. - Arch. Hydrobiol. i Ryb., T. IIII: 3-4: 279-294.

Fridland I.G., 1951: Razmnożenije seldi u jugo-zapadnogo berega Sachalina. - Izw. T.N.I.R.Ch. i O., T. 35:71-82 (in Russian).

Garkina E.A., 1957: Vlijane solenostej na spernu, ikri i licinok ochotskoj seldi。 - Izw. T.N.I.R.Ch. iO., XLV: 30-50 (in Russian).

Hessle Ch., 1925: The herrings along the Baltic coast of Sweden. - Cons. Perrm. Intern. Explor. Mer. Pub. de Cric., 89, Copenhague.

Holliday F.G.T., Blaxter J.H.S., 1960: The effects of salinity on the developing eggs and larvae of the herring. - J. mar. biol. Asss. U.K.,! 39: 591-603.

Kryżanowskij S.G., 1956: Razwite salaki w wode powysenoj solenosti. - Wop. Ich., Wyp. 6: 100-104 (in Russian)。

Lubieniecki B., Zawadzki M., 1980: Biologiczne badania podwodne na Północno-Zachodnim Atlantyku dla potrzeb rybołówstwa. [Biological underwater surveys on the North-Western Atlantic Ocean for the fishery needs.] - Marikultura. MIR. Gdynia. 7-8.

McMynn R.G., Hoar W.S., 1953: Effects of salinity on the development of the development of the Pacific herring. - Canad. J. Zool., 31: 417-432.

Nikolski G., 1970: Ichtiologia szczegółowa. [Detailed ichthy ology]. - PWRiL, Warszawa.

Wawrzyniec Wawrzyniak

\section{PRÓBA SZTUCZNEGO TAREA I INKUBACJI IKRY ŚLEDZIA (CLUPEA HARENGUS L.) Z ZATOKI PUCKIEJ}

\section{STRESZCZENIE}

Przeprowadzono tarło i inkubację ikry śledzia wiosennego (Clupea harengus L.) trącego się w Zatoce Puckiej. Przeprowadzając sztuczne tarło i zapłodnienie ikry zwracano uwagę na procent zapłodnienia. Przemywając zapłodnioną ikrę wodą morską zmieszaną z mlekiem, obserwowano czy 
ikra traci właściwości klejące. Stwierdzono, że zapłodnienie ikry wynosi ponad $90 \%$, natomiast znacznie jest mniejsze gdy zapładniana ikra przemywana jest wodą zmieszaną z mlekiem (tab. 1). Ikra przemywana wodą zmieszaną z mlekiem nie traci w łaściwości klejący ch. Wykorzystując właściwości klejące ikry, wy tarto i zapłodniono ją na siatce do k tórej się przykleiła. Siatkę z przyklejoną ikrą zatopiono w zatoce. Ikrę w ten sposób inkubowano aż do wylęgu prowadząc obserwacje. Równollegle prowadzono obserwacje nad inkubacją ikry w pły tkach Petriego. Ikrę w jednym i drugim przypadku inkubowano $w$ wodzie $o$ tych samych parametrach to znaczy w temperaturze od $9^{\circ} \mathrm{C}$ do $14^{\circ} \mathrm{C}$, zasoleniu $4,3 \%$ i zawartości tlenu $9 \mathrm{mg} / \mathrm{dm}^{3}$. W trakcie inkubacji określono poszczególne etapy rozwoju w stopniodniach (tab.2): Stwierdzono również, że ikra w dużych skupiskach posiada mniejsze zapłodnienie, szybko bieleje a larwy wylęgające się z ikry znajdującej się $\mathrm{w}$ takich skupiskach posiadają różnego ty pu zmiany teratologiczne.

Author's address:

Dr. Wawrzyniec Wawrzyniak

ul. Żỳmierskiego 11

84-140 Jastarnia

Polska (Poland) 